\title{
Anti-corrosion ability of some surfactants based on corn oil and monoethanolamine
}

\author{
Ismayil T. Ismayilov' ${ }^{1,2}$, Hany M. Abd El-Lateef ${ }^{3}$, Vagif M. Abbasov $^{1}$, Sevindj A. Mamedxanova ${ }^{1}$, \\ Ulviyya C. Yolchuyeva ${ }^{1}$, Chimnaz K. Salmanova ${ }^{1}$ \\ ${ }^{1}$ Mamedaliev Institute of Petrochemical Processes, National Academy of Sciences of Azerbaijan, AZ1025 Baku, Azerbaijan \\ ${ }^{2}$ Faculty of Chemistry, Lomonosov Moscow State University, 119991, GSP-1, 1-3 Leninskiye Gory, Moscow, Russia \\ ${ }^{3}$ Chemistry Department, Faculty of Science, Sohag University, 82524 Sohag, Egypt
}

\section{Email address:}

Hany_shubra@yahoo.co.uk(H. M. A. El-Lateef)

\section{To cite this article:}

Ismayil T. Ismayilov, Hany M. Abd El-Lateef, Vagif M. Abbasov, Sevindj A. Mamedxanova, Ulviyya C. Yolchuyeva, Chimnaz K. Salmanova. Anti-Corrosion Ability of Some Surfactants Based on Corn Oil and Monoethanolamine. American Journal of Applied Chemistry. Vol. 1, No. 5, 2013, pp. 79-86. doi: 10.11648/j.ajac.20130105.11

\begin{abstract}
The new group of surfactants was synthesized based on corn oil and monoethanolamine and their inhibiting action on the corrosion of mild steel in $\mathrm{CO}_{2}$-saturated solution was investigated by means of potentiodynamic polarization and linear polarization resistance corrosion rate. The results revealed that, the studied surfactants were an excellent inhibitors and the inhibition efficiencies obtained from potentiodynamic polarization and Linear polarization resistance corrosion rate were in good agreement. Potentiodynamic polarization studies clearly revealed that surfactants acted essentially as the mixed-type inhibitors. Thermodynamic and kinetic parameters were obtained from potentiodynamic polarization, which suggested that at $323 \mathrm{~K}$, the adsorption of inhibitors on the metal surface obeyed Langmuir adsorption isotherm model
\end{abstract}

Keywords: Corrosion, Surfactants, Corn oil, Monoethanolamine

\section{Introduction}

Carbon dioxide corrosion of mild steel is a major problem in the oil and gas industry, and it occurs at all stages of production from down hole to surface equipment and processing facilities [1]. Notably, the corrosion of mild steel in wet gas and multiphase pipelines is responsible for lost production and costly repairs. Aqueous carbon dioxide (carbonic acid) is corrosive and corrodes the carbon steel pipelines. Carbon dioxide corrosion has been of interest to researchers in oil industries for many years and there exists many theories about the mechanism of $\mathrm{CO}_{2}$ corrosion [2.3].

The use of inhibitors is one of the most practical approaches for protecting metals against corrosion [4-8]. These compounds can be adsorbed on metal surfaces, block the active sites, and decrease the corrosion rate. The adsorption ability of inhibitors onto the metal surface depends on the nature and surface charge of metal, chemical composition of electrolytes, and molecular structure and electronic characteristics of inhibitor molecules. The inhibition of steel corrosion using different types of surfactants has been investigated by many workers [9-13].

The paper aims at investigation of the effectiveness of the new synthesized, environmental friendly surfactants on the corrosion rate of mild steel in $\mathrm{CO}_{2}$-saturated solution.

\section{Materials and Methods}

\subsection{Chemical Composition of Mild Steel Alloy}

Electrodes are made of mild steel grade $080 \mathrm{~A} 15$ and have an area of $4.55 \mathrm{~cm}^{2}$. The Chemical composition of mild steel used in this study was given in Table 1. The data was provided by European Corrosion Supplies Ltd. 
Table 1. Chemical composition of mild steel alloy.

\begin{tabular}{cccccccccc}
\hline Element & Si & Ni & Cr & C & S & P & Mn & Fe \\
\hline Content, (wt. \%) & 0.24 & 0.01 & 0.10 & 0.18 & 0.05 & 0.05 & 0.50 & Balance \\
\hline
\end{tabular}

\subsection{Synthesis of Surfactants}

Corn oil was reacted with monoethanolamine for 14 hours at $150-160{ }^{\circ} \mathrm{C}$. These processes produce fatty acid monoethanolamine amide. Based on the last prepared compound sulfating syntheses were performed. The product is sulfated fatty acid monoethanolamine amide. Five types from surfactants were synthesized in high purity by the following composition: $\left[\mathrm{R}-\mathrm{CH}-\left(\mathrm{OSO}_{3} \mathrm{M}\right)-\mathrm{CONH}-\mathrm{CH}_{2}-\mathrm{CH}_{2}-\right.$ $\mathrm{OH}$ ] (where $\mathrm{M}=\mathrm{Na}, \mathrm{K}, \mathrm{NH}_{4},-\mathrm{NH}-\mathrm{CH}_{2}-\mathrm{CH}_{2}-\mathrm{OH}$ and $-\mathrm{N}$ $\left.\left(\mathrm{CH}_{2}-\mathrm{CH}_{2}-\mathrm{OH}\right)_{2}\right)$. List of the synthesized surfactants are shown in Table 2. The chemical structure of the synthesized surfactants was characterized by using FT-IR, Spectrum BX spectrometer using $\mathrm{KBr}$ disks.

\subsection{Preparation of Solutions}

The aggressive solution, $1 \% \mathrm{NaCl}$, was prepared by dissolving of analytical grade $\mathrm{NaCl}$ in distilled water. The concentration range of the prepared surfactants was from 25 to $100 \mathrm{ppm}$ used for corrosion measurements. All inhibitors solutions were prepared using a mixture from distilled water and alcohol in a different ratio.

\subsection{Corrosion Measurements}

The measurements were performed on the rotating cylinder electrode. This electrode was used for one time. The reference electrode was $\mathrm{Ag} / \mathrm{AgCl}$ Electrode to which all potentials are referred.

Before beginning the experiment, the prepared $1 \%$ - of $\mathrm{NaCl}$ solution was stirred by a magnetic stirrer for $60 \mathrm{~min}$ in $1000 \mathrm{ml}$ cell. Then this cell was thermostated at a temperature $50^{\circ} \mathrm{C}$ for 1 hour under a pressure of 0.9 bars. The solution was saturated with carbon dioxide. To remove any surface contamination and air formed oxide, the working electrode was kept at $-1500 \mathrm{mV}(\mathrm{Ag} / \mathrm{AgCl})$ for 5 min in the tested solution, disconnected shaken free of adsorbed hydrogen bubbles and then cathodic and anodic polarization was recorded. ACM Gill AC instrument connected with a personal computer was used for the measurements.

\subsubsection{Potentiodynamic Polarization Measurements}

The extrapolation of cathodic and anodic Tafel lines was carried out in a potential range $\pm 100 \mathrm{mV}$ with respect to corrosion potential $\left(E_{\text {corr }}\right)$ at scan rate of $1 \mathrm{mV} / \mathrm{s}$.

\subsubsection{Linear Polarization Resistance Corrosion Rate}

The LPR method is ideal for plant monitoring offering an almost instantaneous indication of corrosion rate, allowing for quick evaluation of remedial action and minimizing unscheduled downtime. The prepared $1 \%$ - of the solution sodium chloride was stirred by a magnetic stirrer for 60 min in $4000 \mathrm{ml}$. The prepared solution poured into the 4 glass beakers (1000 $\mathrm{ml}$ for each one). Then these beakers were placed on a heater at $50^{\circ} \mathrm{C}$ for 1 hour under a pressure of 0.9 bars. The solution was saturated with carbon dioxide. After that, the electrodes were placed in the medium and are connected through a potentiometer ACM GILL AC. The surface of working electrode is cleaned by acetone before using, these electrodes are using for one time. After 1 hour, except for 1 beaker, the remaining 3 is fed with the suitable amount of inhibitor and continued supply of $\mathrm{CO}_{2}$ under pressure of 0.9 bar until the end of the experiment.

The potential of the working electrode was varied by a CoreRunning programme (Version 5.1.3.) through an ACM instrument Gill AC. The CoreRunning programme converts a corrosion current in $\mathrm{mA} / \mathrm{cm}^{2}$ to a corrosion rate in $\mathrm{mm} /$ year. A cylindrical mild steel rod of the composition 080A15 GRADE STEEL was used as a working electrode. Gill AC technology allows measure DC and AC signals using standard Sequencer software. A small sweep from typically $-10 \mathrm{mV}$ to $+10 \mathrm{mV}$ at $10 \mathrm{mV} / \mathrm{min}$ around the rest potential is performed.

Table 2. List of the synthesized surfactants includes, code number, name and structure.

\begin{tabular}{|c|c|c|c|}
\hline $\begin{array}{l}\text { Code number of the } \\
\text { inhibitor }\end{array}$ & Name and abbreviation & Structure & $\begin{array}{c}\text { molecular } \\
\text { weight }(\mathrm{g} / \mathrm{mol})\end{array}$ \\
\hline $\mathbf{I}$ & $\begin{array}{l}\text { Sodium salt of sulfated fatty acid monoethanolamine } \\
\text { amide (SS) }\end{array}$ & $\mathrm{R}-\left(\mathrm{CH}_{2}\right)_{8}-\mathrm{CH}-\left(\mathrm{CH}_{2}\right)_{7}-\mathrm{C}-\mathrm{NH}-\mathrm{CH}_{2}-\mathrm{CH}_{2}-\mathrm{OH}$ & 397 \\
\hline II & $\begin{array}{l}\text { Potassium salt of sulfated fatty acid monoethanolamine } \\
\text { amide } \\
\text { (PS) }\end{array}$ & $\mathrm{R}-\left(\mathrm{CH}_{2}\right)_{8}-\mathrm{CH}-\left(\mathrm{CH}_{2}\right)_{7}$-C $\left.\right|_{\mathrm{O}-\mathrm{NH}-\mathrm{CH}_{2}-\mathrm{CH}_{2}-\mathrm{OH}} ^{\mathrm{O}}$ & 413 \\
\hline
\end{tabular}




\begin{tabular}{|c|c|c|c|}
\hline $\begin{array}{l}\text { Code number of the } \\
\text { inhibitor }\end{array}$ & Name and abbreviation & Structure & $\begin{array}{c}\text { molecular } \\
\text { weight }(\mathrm{g} / \mathrm{mol})\end{array}$ \\
\hline III & $\begin{array}{l}\text { Ammonium salt of sulfated fatty acid monoethanolamine } \\
\text { amide } \\
\text { (AS) }\end{array}$ & 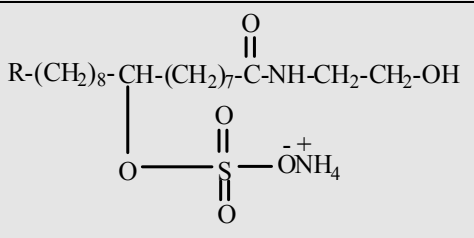 & 391 \\
\hline IV & $\begin{array}{l}\text { Sulfated fatty acid monoethanolamine amide - } \\
\text { monoethanolamine complex (MC) }\end{array}$ & $\mathrm{R}-\left(\mathrm{CH}_{2}\right)_{8}-\mathrm{CH}-\left(\mathrm{CH}_{2}\right)_{7} \mathrm{O}-\mathrm{C}-\mathrm{NH}-\mathrm{CH}_{2}-\mathrm{CH}_{2}-\mathrm{OH}$ & 423 \\
\hline $\mathbf{V}$ & $\begin{array}{l}\text { Sulfated fatty acid monoethanolamine amide - } \\
\text { diethanolamine Complex (DC) }\end{array}$ & 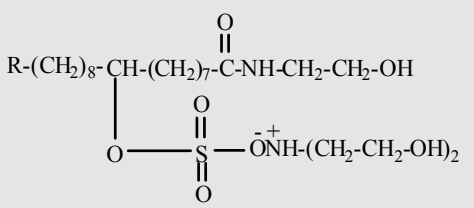 & 472 \\
\hline
\end{tabular}

Table 3. Corrosion parameters obtained from Tafel polarization for mild steel in $\mathrm{CO}_{2}$-saturted solution in the absence and presence of different concentrations of the prepared surfactants at $50{ }^{\circ} \mathrm{C}$.

\begin{tabular}{|c|c|c|c|c|c|c|c|}
\hline $\begin{array}{l}\text { Inhibitors } \\
\text { Code }\end{array}$ & $\begin{array}{c}\text { Conc. of } \\
\text { inhibitor }(\mathrm{ppm})\end{array}$ & $\begin{array}{c}-E_{\text {corr }}(\mathrm{mV} \\
(\mathrm{Ag} / \mathrm{AgCl}))\end{array}$ & $\begin{array}{c}I_{\text {corr }} \\
\left(\mathrm{mAcm}^{-2}\right)\end{array}$ & $\begin{array}{c}\beta_{\mathrm{a}} \\
\left(\mathrm{mVdec}^{-1}\right)\end{array}$ & $\begin{array}{c}-\beta_{c} \\
\left(\mathrm{mVdec}^{-1}\right)\end{array}$ & $\theta$ & $\eta \%$ \\
\hline Absence & 0.0 & 687 & 0.389 & 60 & 111 & --- & --- \\
\hline \multirow{4}{*}{ I } & 25 & 688 & 0.03894 & 39 & 90 & 0.89 & 89.99 \\
\hline & 50 & 699 & 0.01299 & 33 & 91 & 0.96 & 96.66 \\
\hline & 75 & 689 & 0.0112 & 35 & 95 & 0.97 & 97.12 \\
\hline & 100 & 680 & 0.00759 & 37 & 93 & 0.98 & 98.05 \\
\hline \multirow{4}{*}{ II } & 25 & 681 & 0.04423 & 36 & 93 & 0.88 & 88.63 \\
\hline & 50 & 692 & 0.01299 & 36 & 89 & 0.96 & 96.66 \\
\hline & 75 & 682 & 0.01155 & 38 & 92 & 0.97 & 97.03 \\
\hline & 100 & 673 & 0.00856 & 35 & 96 & 0.97 & 97.80 \\
\hline \multirow{4}{*}{ III } & 25 & 684 & 0.04407 & 36 & 94 & 0.88 & 88.67 \\
\hline & 50 & 695 & 0.0175 & 40 & 92 & 0.95 & 95.50 \\
\hline & 75 & 685 & 0.01369 & 36 & 91 & 0.96 & 96.48 \\
\hline & 100 & 676 & 0.00708 & 34 & 89 & 0.98 & 98.18 \\
\hline \multirow{4}{*}{ IV } & 25 & 685 & 0.12783 & 40 & 90 & 0.67 & 67.14 \\
\hline & 50 & 696 & 0.0883 & 38 & 95 & 0.77 & 77.30 \\
\hline & 75 & 686 & 0.07617 & 37 & 94 & 0.80 & 80.42 \\
\hline & 100 & 677 & 0.06531 & 34 & 93 & 0.83 & 83.21 \\
\hline \multirow{4}{*}{$\mathbf{V}$} & 25 & 688 & 0.21294 & 33 & 90 & 0.45 & 45.26 \\
\hline & 50 & 699 & 0.1724 & 35 & 87 & 0.55 & 55.68 \\
\hline & 75 & 689 & 0.13008 & 37 & 90 & 0.66 & 66.56 \\
\hline & 100 & 680 & 0.07247 & 38 & 88 & 0.81 & 81.37 \\
\hline
\end{tabular}

\section{Results and Discussions}

\subsection{Chemical Structure of the Synthesized Surfactants}

The structural characteristic of fatty acid monoethanolamine amide before and after sulfating processes was confirmed by FT-IR spectroscopy in the range $4000-500 \mathrm{~cm}^{-1}$. The peak at about $1750 \mathrm{~cm}^{-1}$ is duo to the $-\mathrm{NH}-\mathrm{C}=\mathrm{O}$ group, whereas the peak at $1451 \mathrm{~cm}^{-1}$ arises due to $\mathrm{C}=\mathrm{C}$ bond. This bond was broken after sulfating process. The peak at $1385 \mathrm{~cm}^{-1}$ is due to $\mathrm{S}-\mathrm{O}$ stretching absorption bands. FTIR spectrum showed that, the presence of $\mathrm{OH}$ group after sulfating process. It indicates the almost complete removal of $\mathrm{C}=\mathrm{C}$ bond by sulfating process and the process occur only on $\mathrm{C}=\mathrm{C}$. 


\subsection{The Extrapolation of Cathodic and Anodic Tafel Lines}

Figure 1 shows the influence of inhibitor I concentrations on the Tafel cathodic and anodic polarization characteristics of mild steel in $\mathrm{CO}_{2}$-saturated solution at scan rate $1 \mathrm{mV} / \mathrm{s}$ and at $50{ }^{\circ} \mathrm{C}$. Corrosion parameters were calculated on the basis of cathodic and anodic potential versus current density characteristics in the Tafel potential region $[14,15]$. Steady state of open circuit corrosion potential $\left(E_{\text {corr }}\right)$ for the investigated electrode in the absence and presence of the studied inhibitor was attained after 45-60 min from the moment of immersion. Corrosion current density $\left(I_{\text {corr }}\right)$ of the investigated electrodes was determined [16], by extrapolation of cathodic and anodic Tafel lines to corrosion potential $\left(E_{\text {corr }}\right)$. The inhibition efficiency expressed as percent inhibition $(\eta \%)$ is defined as:

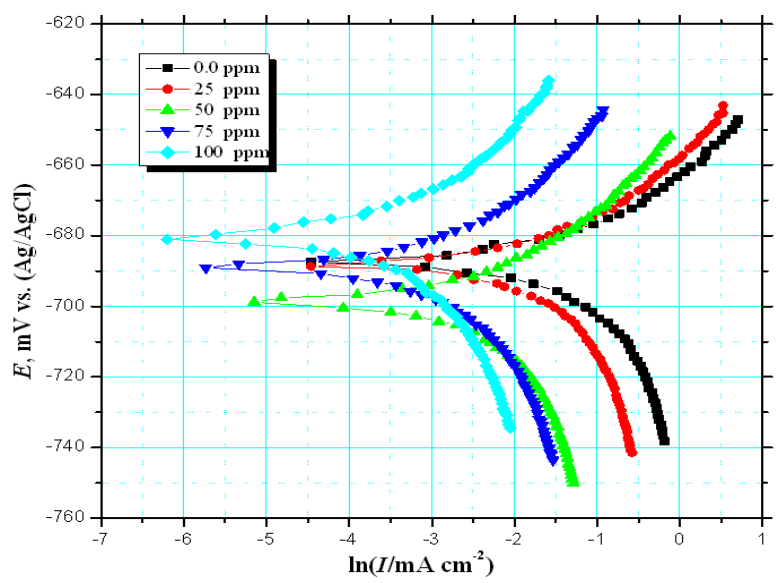

Fig 1. Tafel polarization curves for mild steel in $\mathrm{CO}_{2}$-saturated $1 \% \mathrm{NaCl}$ solution containing different concentration of inhibitor I at $50{ }^{\circ} \mathrm{C}$.

$$
\eta \%=\frac{I_{\text {uninh }}-I_{\text {inh }}}{I_{\text {uninh }}} \times 100
$$

Where $I_{\text {uninh. }}$ and $I_{\text {inh. }}$ are the uninhibited and inhibited corro sion currents. The inhibited corrosion currents are those det ermined in the presence of the studied surfactants used in th is investigation. The uninhibited corrosion currents were de termined in pure (inhibitor free) $\mathrm{CO}_{2}$-saturated $1 \% \mathrm{NaCl}$ so lution at the same temperature. It can be seen that the prese nce of surfactants molecule results a marked shift in both ca thodic and anodic branches of the polarization curves towar ds lower current densities. This means that, the inhibitors af fect both cathodic and anodic reactions. It was found that, $b$ oth anodic and cathodic reactions of mild steel electrode co rrosion were inhibited with increasing concentration of synt hesized inhibitors. These results suggest that not only the a ddition of synthesized inhibitors reduce anodic dissolution but also retard the hydrogen evolution reaction. The electro chemical parameters $E_{\text {corr }}, I_{\text {corr }}$, inhibition efficiency $(\eta \%)$, a nodic and cathodic Tafel slopes $\left(\beta_{\mathrm{a}}, \beta_{\mathrm{c}}\right)$ obtained from the $\mathrm{p}$ olarization measurements were listed in Table 3. The data e xhibited that, the corrosion current density $\left(I_{\text {corr }}\right)$ decreases, and the inhibition efficiency $(\eta \%)$ increases as the concentr ation of inhibitors is increased. These results suggest that re tardation of the electrodes processes occurs, at both cathodi $\mathrm{c}$ and anodic sites, as a result of coverage of these sites by $\mathrm{s}$ urfactants molecules. However, the maximum decrease in $I_{\mathrm{c}}$ orr was observed for (I) and the inhibition efficiency of the $i$ nvestigated inhibitors was increased in the following order: I $>$ III $>$ II $>$ IV $>$ V at $100 \mathrm{ppm}$. The increase of inhibitor effi ciency with increasing the concentration can be interpreted on the basis of the adsorption amount and the coverage of $s$ urfactants molecules, increases with increasing concentratio $\mathrm{n}[17,18]$. The $E_{\text {corr }}$ values of all synthesized inhibitors wer e shifted slightly toward both cathodic and anodic direction $\mathrm{s}$ and did not show any definite trend in $\mathrm{CO}_{2}$-saturated brin e. This may be considered due to the mixed-type behavior o $\mathrm{f}$ the studied inhibitors. It can be observed that, the shift in $E_{\text {corr }}$ is characteristic of anodic and anodic/cathodic inhibito $\mathrm{r}$ [19].

The change in $\beta_{\mathrm{a}}$ and $\beta_{\mathrm{c}}$ values as shown in Table 3 indicates that adsorption of synthesized surfactants modify the mechanism of anodic dissolution as well as cathodic hydrogen evolution. In other words, the inhibitor decreases the surface area for corrosion of the investigated metal, and only causes inactivation of a part of the surface with respect to corrosive medium [18]. On the other hand, the cathodic Tafel slopes $\left(\beta_{\mathrm{c}}\right)$ are also found to be greater than the respective anodic Tafel slopes $\left(\beta_{\mathrm{a}}\right)$. These observations are correlated with the fact that the cathodic exchange-current density values are less than those of the anodic counter parts. It can be concluded that the overall kinetics of corrosion of mild steel alloy in $\mathrm{CO}_{2}$ saturated solution are under cathodic control.

\subsection{LPR Corrosion Rate}

LPR test has been performed in brine saturated with $\mathrm{CO}_{2}$ at $50{ }^{\circ} \mathrm{C}$, in turbulence fluid stream during 20 hours. Figure 2 shows that, the change in corrosion rate (CR) with time for mild steel in $\mathrm{CO}_{2}$-saturated $1 \% \mathrm{NaCl}$ solution containing different concentrations form inhibitors I (A), II (B) and V (C) at $50{ }^{\circ} \mathrm{C}$. The inhibitor was added after 1 hour of exposure because at this time the corrosion potential got stable, allowing the measurement of the $\mathrm{CR}$ prior the injection of the inhibitor. The initial corrosion rate, without inhibitor, was measured to be between 3.45 and $5.03 \mathrm{~mm}$ $\mathrm{y}^{-1}$. It can be observed from Figure 2 that, the CR, in the absence of inhibitors, tends to increase with time. The increase in $\mathrm{CR}$ has been attributed to the galvanic effect between the ferrite phase and cementite $\left(\mathrm{Fe}_{3} \mathrm{C}\right)$ which is a part of the original steel in the non-oxidized state and accumulates on the surface after the preferential dissolution of ferrite $(\alpha-\mathrm{Fe})$ into $\mathrm{Fe}^{2+}[20] . \mathrm{Fe}_{3} \mathrm{C}$ is known to be less active than the ferrite phase. Therefore, there is a preferential dissolution of ferrite over cementite, working the former as the anode and latter as the cathode, favoring the hydrogen evolved reaction (HER) during the corrosion process [21].

Variation of the corrosion rate for inhibitors I, II and V at different concentrations are presented in Figure 2. Corrosion parameters were calculated on the basis of LPR 
corrosion rate test. The inhibition efficiency $(\eta \%)$ and surface coverage $(\theta)$ were calculated according to the following equations:

$$
\begin{gathered}
\eta \%=\frac{C R_{0}-C R_{i}}{C R_{0}} \times 100 \\
\text { Surface coverage }(\theta)=\theta=1-\frac{C R_{i}}{C R_{0}}
\end{gathered}
$$

where $C R_{\mathrm{o}}$ is the corrosion rate without inhibitor and $C R_{\mathrm{i}}$ is the corrosion rate when inhibitor is present. It can be seen that the presence of inhibitors results a high decrease in the rate of corrosion. In the case of these inhibitors, the corrosion rate decreases as the inhibitor concentration increases, getting maximum inhibition efficiency ranged between 82.19 and $99.17 \%$ at 100 ppm after 20 hour of exposure (Table 4). This trend may results from the fact that adsorption and surface coverage increase with the increase in concentration; thus the surface is effectively separated from the medium.

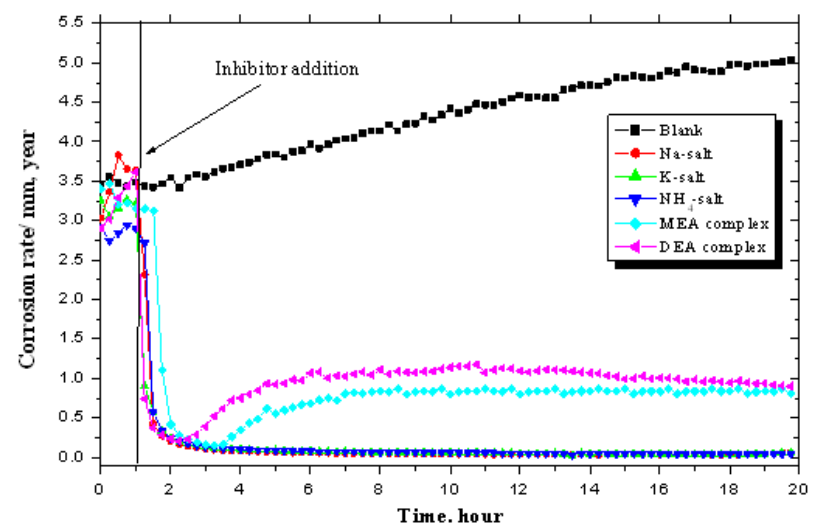

Figure 3. Variation of the Corrosion rate with time for carbon steel in $\mathrm{CO}_{2}$-saturated $1 \% \mathrm{NaCl}$ solution containing $100 \mathrm{ppm}$ of different inhibitors at $50^{\circ} \mathrm{C}$

Table 4 shows the calculated values of corrosion rates, the inhibition efficiencies and the surface coverage in the absence and presence of different concentrations of different inhibitors at $50{ }^{\circ} \mathrm{C}$. The data exhibited that, the corrosion rates, the inhibition efficiencies and the surface coverage are found to depend on the concentrations of the inhibitors. The corrosion rate (CR) are decreased, and the inhibition efficiencies $(\eta \%)$ and the surface coverage $(\theta)$ are increased with the increase of the surfactant concentrations. This indicates that the inhibitory action of the inhibitors against mild steel corrosion can be attributed to the adsorption of these molecules on the metal surface, limits the dissolution of mild steel, and the adsorption amounts of surfactants on mild steel increase with concentrations in the corrosive solutions. The maximum decrease in the corrosion rate was observed for inhibitor (I) and the inhibition efficiency of the investigated surfactants was increased in the following order: I $>$ III $>$ II $>$ IV $>$ V (Fig.3). There was an increase in the efficiency of corrosion inhibition with increasing concentration, Due to their containment of $\mathrm{C}=\mathrm{O}$, oxygen, nitrogen and sulfur groups these molecules contribute towards inhibition, and effectively protecting the surface. Adsorption of these surface active molecules forms thin inhibitor films on the metal surface which in order relatively isolate the metal surface from the corrosive environment causing much reduced corrosion rates. Inhibition efficiency of these films depends on various factors including but not limited to corrosivity of the environment, concentration of the active inhibitor molecules, any synergetic effects with other molecules present in the environment and/or flow/shear effects.

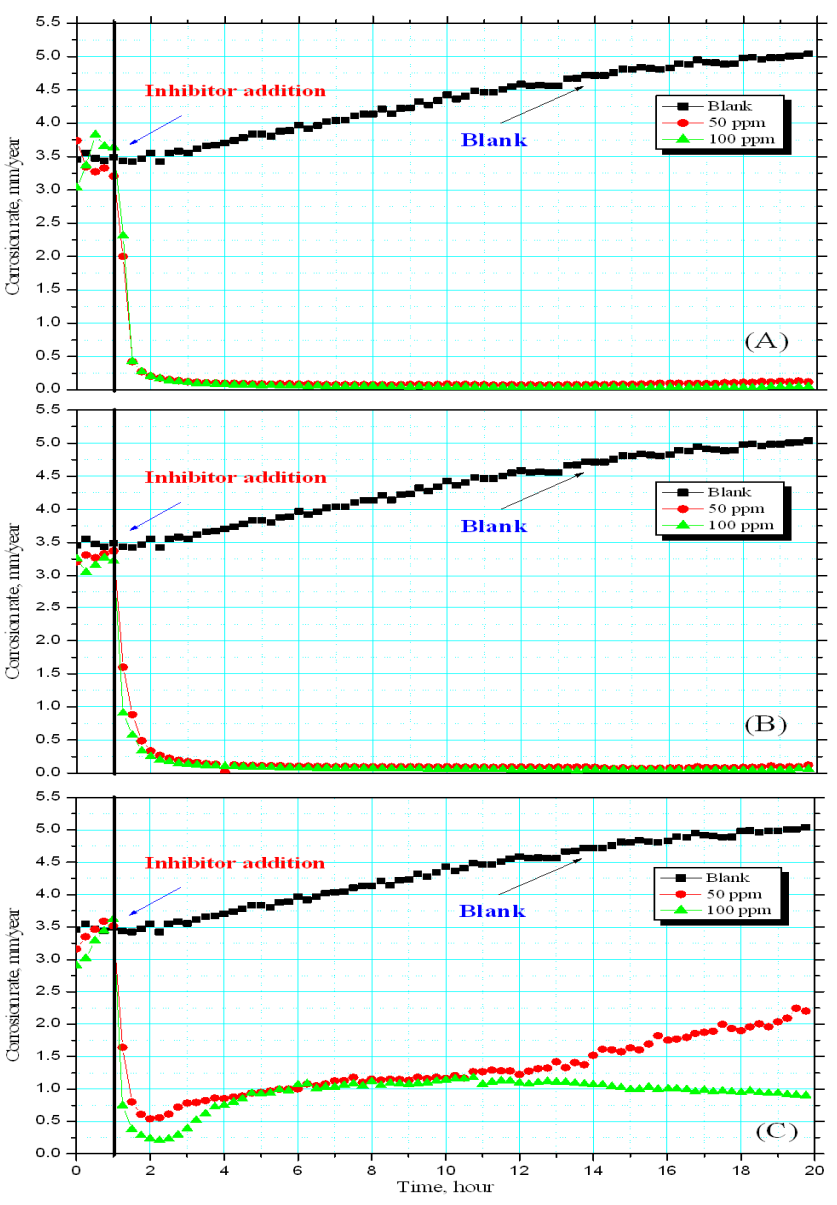

Figure 2. Variation of the Corrosion rate with time for carbon steel in $\mathrm{CO}_{2}$-saturated $1 \% \mathrm{NaCl}$ solution containing different concentrations of inhibitors (a) I, (b) II and (c) V at $50^{\circ} \mathrm{C}$.

The high inhibition efficiency obtained in $\mathrm{CO}_{2}$ - saturated $1 \% \mathrm{NaCl}$ solution in the presence of studied complex surfactants can be attributed to the formation of a protective film of iron carbonate $\left(\mathrm{FeCO}_{3}\right)$ in the metal surface [2]. The properties of the formed layers and its effect on the corrosion rate are important factors to take into account when studying the corrosion of mild steels in $\mathrm{CO}_{2}$-saturated solutions. Ogundele and White suggested that, iron carbonate, $\mathrm{FeCO}_{3}$, may be important in the formation of protective layers on steel surface [22]. The formation of iron carbonate can be explained by using the following 
Eq.[4].

$$
\mathrm{Fe}^{2+}+\mathrm{CO}_{3}^{2-} \rightarrow \mathrm{FeCO}_{3}
$$

By comparison between inhibition efficiency values $(\eta \%)$ which are calculated from both LPR corrosion rate and extrapolation of anodic and cathodic curves, we find that both have similar trend. In other words, the inhibition efficiency increases with increasing surfactant concentration, and the maximum inhibition efficiency values are obtained at $100 \mathrm{ppm}$ in the case of all investigated surfactants.

Table 4. The corrosion parameters obtained from LPR corrosion rate measurements for mild steel electrode in $\mathrm{CO}_{2}$-saturated $1 \%$ solution of $\mathrm{NaCl}$ in the absence and presence of various concentrations of inhibitors obtained based on corn oil at $50{ }^{\circ} \mathrm{C}$.

\begin{tabular}{|c|c|c|c|c|}
\hline Inhibitors & Concentration, ppm & $\begin{array}{c}\text { Corrosion rate } \\
(\mathrm{mm} / \text { year })\end{array}$ & $\begin{array}{c}\text { Surface coverage } \\
\theta\end{array}$ & $\begin{array}{l}\text { The inhibition } \\
\text { efficiency, } \eta \%\end{array}$ \\
\hline Absence & 0.0 & 5.037 & ----- & ----- \\
\hline \multirow{2}{*}{ I } & 50 & 0.119 & 0.97 & 97.63 \\
\hline & 100 & 0.048 & 0.99 & 99.04 \\
\hline \multirow{2}{*}{ II } & 50 & 0.119 & 0.97 & 97.63 \\
\hline & 100 & 0.061 & 0.98 & 98.78 \\
\hline \multirow{2}{*}{ III } & 50 & 0.1780 & 0.96 & 96.46 \\
\hline & 100 & 0.0414 & 0.99 & 99.17 \\
\hline \multirow{2}{*}{ IV } & 50 & 1.104 & 0.78 & 78.08 \\
\hline & 100 & 0.803 & 0.84 & 84.05 \\
\hline \multirow{2}{*}{ V } & 50 & 2.204 & 0.56 & 56.24 \\
\hline & 100 & 0.897 & 0.82 & 82.19 \\
\hline
\end{tabular}

\subsection{Adsorption Isotherm Studies}

The degree of surface coverage $(\theta)$ for different inhibitor concentrations was evaluated from Potentiodynamic polarization measurements. The best correlation between the experimental results and isotherm functions was obtained at high inhibitor concentrations using the Langmuir adsorption isotherm. The Langmuir isotherm is given by the following equation [23]:

$$
\frac{C_{i n h}}{\theta}=C_{i n h}+\frac{1}{K_{a d s}}
$$

where $K_{\text {ads }}$ is the equilibrium constant of the inhibitor adsorption process and $C_{\text {inh }}$ is the surfactant concentration. The plots of $C_{\text {inh }} / \theta$ vs $C_{\text {inh }}$ yielded straight lines with near unit slopes for all the surfactants showing that the adsorption model of these surfactants follows the Langmuir isotherm with good correlation (as shown in Fig. 4).

The values of $K_{\text {ads }}$ obtained from the Langmuir adsorption isotherm are listed in Table 5, together with the values of the Gibbs free energy of adsorption $\left(\Delta G_{a d s}^{o}\right)$ calculated from [24]

$$
\begin{aligned}
K_{a d s} & =\frac{1}{C_{\text {inh }}} \times \frac{\theta}{1-\theta} \\
\Delta G_{a d s} & =-2.303 R T \log \left(55.5 K_{a d s}\right)
\end{aligned}
$$

Where $R$ is the universal gas constant, $T$ is the thermodynamic temperature and the value of 55.5 is the concentration of water in the solution.

The high values of $K_{\text {ads }}$ for studied surfactants indicate stronger adsorption on the mild steel surface in $\mathrm{CO}_{2}$ saturated solution [25]. The large value of $K_{\text {ads }}$ obtained for the studied surfactants agree with the high inhibition efficiency obtained.

Generally, values of $\Delta G_{a d s}^{o}$ up to $-20 \mathrm{~kJ} \mathrm{~mol}^{-1}$ are consistent with physisorption, while those around $-40 \mathrm{~kJ}$ $\mathrm{mol}^{-1}$ or higher are associated with chemisorption as a result of the sharing or transfer of electrons from organic molecules to the metal surface to form a coordinate bond [26]. In the present study, The values of $\Delta G_{a d s}^{o}$ obtained for studied surfactants on mild steel in $\mathrm{CO}_{2}$-saturated solution ranges between -23.79 and $-21.93 \mathrm{~kJ} \mathrm{~mol}^{-1}$, which are around $-20 \mathrm{~kJ} \mathrm{~mol}^{-1}$ (Table 5). These results indicate that the adsorption mechanism of surfactants on mild steel in $\mathrm{CO}_{2}$ saturated solution is typical physisorption at the studied temperature. physisorption of the surfactant molecules could occur due to the electrostatic interactions between the charged molecules and the charged metal. The negative values obtained for $\Delta G_{a d s}^{o}$ indicate that the adsorption process takes place spontaneously by strong interactions between the inhibitor and the steel surface, as was suggested by the obtained values of $K_{\text {ads }}$. 
Table 5. Thermodynamic parameters for the adsorption of the studied surfactants on mild steel electrode in $\mathrm{CO}_{2}$ - saturated brine.

\begin{tabular}{|c|c|c|c|c|}
\hline $\begin{array}{l}\text { Inhibitors } \\
\text { Code }\end{array}$ & Slope & Regression coefficients, $R^{2}$ & $\begin{array}{c}\boldsymbol{K}_{\text {adss }} \\
\mathbf{M}^{-1} \times 10^{5}\end{array}$ & $\begin{array}{c}\Delta G_{a d s}^{o} \\
\left(\mathbf{k J ~ m o l}^{-1}\right)\end{array}$ \\
\hline I & 1.02 & 0.9876 & 2.211 & -23.79 \\
\hline II & 1.09 & 0.9896 & 3.157 & -22.27 \\
\hline III & 1.02 & 0.9997 & 2.453 & -21.93 \\
\hline IV & 1.05 & 0.9699 & 3.553 & -22.40 \\
\hline $\mathrm{V}$ & 1.02 & 0.9899 & 3.861 & -22.43 \\
\hline
\end{tabular}
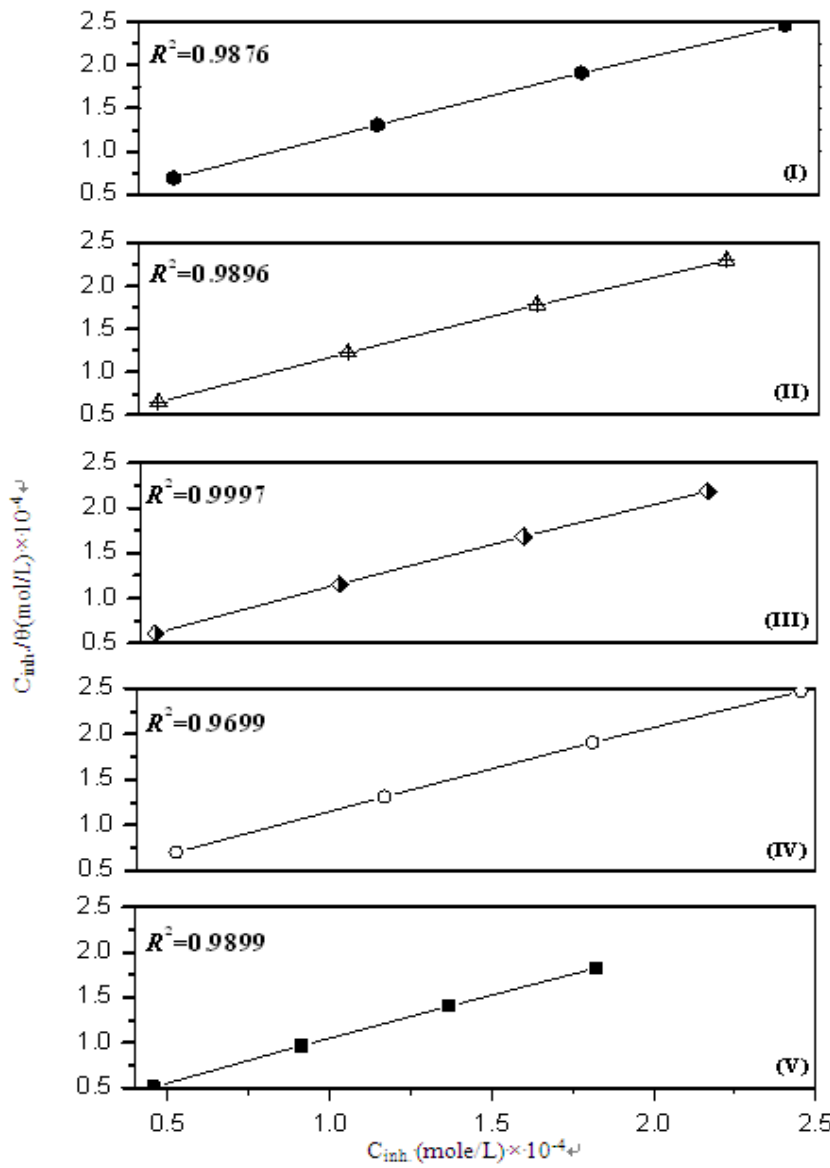

Figure 4. Curve fitting of the corrosion data obtained from Potentiodynamic polarization measurements for carbon steel in $\mathrm{CO}_{2}$ saturated brine containing various concentrations of inhibitors according to Langmuir adsorption isotherm model at $50{ }^{\circ} \mathrm{C}$.

\section{Conclusion}

a) Polarization curves proved that the investigated surfactants were the mixed-type inhibitor for mild steel in $\mathrm{CO}_{2}$-saturated solution.

b) All measurements showed that, inhibitors had excellent inhibition properties for the corrosion of mild steel in $\mathrm{CO}_{2}$-saturated $1 \% \mathrm{NaCl}$ at $323 \mathrm{~K}$, and the inhibition efficiency increased with the concentration of the inhibitor, getting maximum inhibition efficiency ranged between 82.19 and $99.17 \%$ at $100 \mathrm{ppm}$ after 20 hour of exposure.

c) The maximum decrease in the corrosion rate was observed for inhibitor (I) and the inhibition efficiency of the investigated surfactants was increased in the following order: I $>$ III $>$ II $>$ IV $>$ V.

d) The adsorption model obeyed Langmuir adsorption isotherm. The adsorption process was spontaneous. The values of the standard free energies of adsorption indicated that the synthesized surfactants adsorbed on mild steel in $\mathrm{CO}_{2}$-saturated $1 \% \mathrm{NaCl}$ were typical physisorption mechanism.

\section{References}

[1] W. Durnie, R. De Marco, A. Jeerson, B. Kinsella, Harmonic analysis of carbon dioxide corrosion, Corrosion Science 44 (2002) 1213-1221.

[2] V. M. Abbasov, Hany M. Abd El-Lateef, L. I. Aliyeva, I. T. Ismayilov, E. E. Qasimov, Efficient Complex Surfactants from the Type of Fatty Acids as Corrosion Inhibitors for Mild Steel $\mathrm{C} 1018$ in $\mathrm{CO}_{2}$-Environments, Journal of the Korean Chemical Society, 57 (2013) 25-34.

[3] Hany M. Abd El-Lateef, V.M. Abbasov, L.I. Aliyeva, E.E. Qasimov, I.T. Ismayilov, Inhibition of carbon steel corrosion in $\mathrm{CO}_{2}$-saturated brine using some newly surfactants based on palm oil: Experimental and theoretical investigations, Materials Chemistry and Physics 142 (2013) 502-512.

[4] Q. Zhang, Z. Gao , F. Xu, Xia Zou, Adsorption and corrosion inhibitive properties of gemini surfactants in the series of hexanediyl-1,6-bis-(diethyl alkyl ammonium bromide) on aluminium in hydrochloric acid solution, Colloids and Surfaces A: Physicochem. Eng. Aspects 380 (2011) 191-200.

[5] R. Fuchs-Godec, V. Dole cek, A effect of sodium dodecylsulfate on the corrosion of copper in sulphuric acid media, Colloids and Surfaces A: Physicochem. Eng. Aspects 244 (2004) 73-76.

[6] F. AishaAnsari, M. A. Quraishi, Inhibitive Effect of Some Gemini Surfactants as Corrosion Inhibitors for Mild Steel in Acetic Acid Media, Arab J Sci Eng, 36(2011) 11-20.

[7] Hany M. Abd El-Lateef, V. M. Abbasov, L. I. Aliyeva, E. E. Qasimov, I. T. Ismayilov, LPR Corrosion Rate, Weight Loss Measurements and SEM Studies of the Effect of the Some Novel Surfactants as Corrosion Inhibitors for Carbon Steel in $\mathrm{CO}_{2}$-Saturated $1 \% \mathrm{NaCl}$ Solutions, Journal of Surfaces and Interfaces of Materials, 1 (2012) 1-11. 
[8] M.A. Migahed, M. Abd-El-Raouf, A.M. Al-Sabagh, H.M. Abd-El-Bary, Effectiveness of some non ionic surfactants as corrosion inhibitors for carbon steel pipelines in oil fields, Electrochimica Acta 50 (2005) 4683-4689.

[9] L. Qiu, A. Xie, Y. Shen, A novel triazole-based cationic gemini surfactant: synthesis and effect on corrosion inhibition of carbon steel in hydrochloric acid, Materials Chemistry and Physics 91 (2005) 269-273.

[10] Hany M. Abd El-Lateef, V. M. Abbasov, L. I. Aliyeva, E. N. Efremenko, E. E. Qasimov, S. A. Mamedxanova, A novel sulfated Fatty acid amides -based surfactants: synthesis and effect on the corrosion inhibition of carbon steel in $\mathrm{CO}_{2-}$ saturated $1 \% \mathrm{NaCl}$ solution, I. T. Ismayilov, Advances in Materials and Corrosion, 1 (2012) 22-29.

[11] Hany M. Abd El-Lateef, I. T. Ismayilov, V. M. Abbasov, E. N. Efremenko, L. I. Aliyeva, E. E. Qasimov, Green Surfactants from the Type of Fatty Acids as Effective Corrosion Inhibitors for Mild Steel in $\mathrm{CO}_{2}$ - Saturated $\mathrm{NaCl}$ Solution, American Journal of Physical Chemistry. 2(1), (2013) 16-23.

[12] N.A. Negm , A.M. Al Sabagh, M.A. Migahed, H.M. Abdel Bary, H.M. El Din, Effectiveness of some diquaternary ammonium surfactants as corrosion inhibitors for carbon steel in $0.5 \mathrm{M} \mathrm{HCl}$ solution, Corrosion Science 52 (2010) $2122-2132$

[13] R. Fuchs-Godec, Effect of the Nature of the Counterions of N-alkyl Quaternary Ammonium Salts on Inhibition of the Corrosion Process, Acta Chim. Slov. 54 (2007) 492-502.

[14] R. Tremont, H. De Jesus-Cardona, J. Garcia-Orozco, R.J. Castro, C.R. Cabrera, 3-Mercaptopropyltrimethoxysilane as a $\mathrm{Cu}$ corrosion inhibitor in $\mathrm{KCl}$ solution, J. Appl. Electrochem. 30 (2000) 737-743.

[15] J.W. Schultze, K. Wippermann, Inhibition of Electrode processes on copper by AHT in acid solutionElectrochim. Acta , 32 (1987) 823-831.
[16] A. El-Sayed, H. S. Mohran, Hany M. Abd El-Lateef, Inhibitive action of ferricyanide complex anion on both corrosion and passivation of zinc and zinc-nickel alloy in the alkaline solution, Journal of Power Sources 196 (2011) $6573-6582$.

[17] E. Akbarzadeh, M. N. M. Ibrahim, A. A. Rahim, Corrosion Inhibition of Mild Steel in Near Neutral Solution by Kraft and Soda Lignins Extracted from Oil Palm Empty Fruit Bunch, Int. J. Electrochem. Sci., 6 (2011) 5396 - 5416.

[18] A. El-Sayed, Hossnia S. Mohran, H.M. Abd El-Lateef, The inhibition effect of 2,4,6-tris (2-pyridyl)-1,3,5-triazine on corrosion of tin, indium and tin-indium alloys in hydrochloric acid solution Corros. Sci. 52 (2010) 19761984.

[19] D. A. López, S. N. Simison, S. R. de Sánchez, Corr. Sci. 47 (2005) 735-775.

[20] N. Staicopolus, J. Electrochem. Soc. 110 (1963) 1121-1124.

[21] J. Crolet, Thevenot N, Nesic S, Corrosion, 54 (1998) 194203.

[22] G. I. Ogundele, W. E. White, Corrosion, 42(2) (1986) 71.

[23] M. Lebrini, M. Traisnel, M. Lagrenee, B. Mernari, F. Bentiss, Inhibitive properties, adsorption and a theoretical study of 3,5-bis(n-pyridyl)-4-amino-1,2,4-triazoles as corrosion inhibitors for mild steel in perchloric acid. Corros Sci 50 (2008) 473

[24] R. Solmaz, G. Kardas, M. Culha, B.Yazici, M. Erbil, Electrochim. Acta, 53 (2008) 5941.

[25] S.A. Refay, F. Taha, A.M. Abd El-Malak, Appl. Surf. Sci. 236 (2004) 175-185.

[26] Z. Szklarska-Smialowska, J. Mankowski, Crevice corrosion of stainless steels in sodium chloride solution, Corros. Sci. 18 (1978) 953-960. 